\title{
CONTRIBUTION OF ORGANIC BULKING MATERIALS ON CHEMICAL QUALITY OF SEWAGE SLUDGE VERMICOMPOST
}

\author{
Efeito de materiais de volume na qualidade química do vermicomposto de lodo de esgoto
}

\author{
Kazem Hashemimajd ${ }^{1}$, Shahzad Jamaati-e-Somarin ${ }^{2}$
}

\begin{abstract}
Vermicomposting is at suitable methods for stabilization and converting of sewage sludge into useful products. To investigate the effects of bulking material on vermicompost quality, an experiment was conducted in a factorial design with three replications. In this experiment, the final dried sludge in lagoons was mixed with bulking materials (woodchips, three leaves, and wheat straw) in four mixing proportion with swage sludge $(0,15,30$ and $45 \%, \mathrm{~V} / \mathrm{V})$. Chemical properties of bulking materials, sewage sludge, and produced vermicomposts were determined. Vermicomposts had relatively low $\mathrm{pH}$ and electrical conductivity (EC). The nutrients content of vermicompost, especially $\mathrm{N}, \mathrm{P}, \mathrm{Fe}$, and $\mathrm{Zn}$, were high. These properties showed its suitable quality for use in agriculture. Heavy metals concentrations of vermicomposts, except $\mathrm{Zn}$, were lower than recommended values by EPA. Mixing of Bulking materials with sewage sludge decreased $\mathrm{pH}, \mathrm{N}, \mathrm{Pb}, \mathrm{Co}$, and $\mathrm{Cd}$, but increased $\mathrm{Ca}, \mathrm{Mg}, \mathrm{Fe}, \mathrm{Cu}, \mathrm{Mn}, \mathrm{Zn}$, and $\mathrm{Ni}$ content of produced vermicomposts. In most cases, the concentrations of nutrients were higher in $30 \%$ mixing proportion. Therefore, $30 \%$ (v/v) mixing of bulking material with sewage sludge is recommended for vermicompost production.
\end{abstract}

Index terms: Vermicompost, sewage sludge, bulking materials, heavy metals, Eisenia foetid.

\section{RESUMO}

A vermicompostagem é um métodos adequados para a estabilização e conversão de lodo de esgoto em produtos úteis. Para investigar o efeito de aumentar o volume de material sobre a qualidade do vermicomposto, foi conduzido um experimento em esquema fatorial com três repetições. Neste experimento, o lodo final seco em lagoas foi misturado com materiais de volume (lascas de madeira, três folhas e palha de trigo) em quatro proporções de mistura $(0,15,30$ e $45 \%$ V / V) com lodo de esgoto. Propriedades químicas dos materiais de amontoamento, lodo de esgoto e vermicompostos produzidos foram determinados. Vermicomposto apresentaram $\mathrm{pH}$ relativamente baixo e CE. O seu teor de nutrientes, especialmente N, P, Fe e Zn foram elevados. Essas propriedades mostrou sua qualidade adequada para utilização na agricultura. Concentrações de metais pesados de vermicompostos, com exceção do zinco, foram menores do que os valores recomendados pela EPA. A mistura de materiais Bulking com lodo de esgoto diminuiu o pH, $\mathrm{N}, \mathrm{Pb}$, $\mathrm{Co}$ e $\mathrm{Cd}$, mas aumentou a concentração de $\mathrm{Ca}, \mathrm{Mg}, \mathrm{Fe}, \mathrm{Mn}, \mathrm{Cu}, \mathrm{Zn}, \mathrm{Ni}$ no vermicomposto produzido. Na maioria dos casos, as concentrações de nutrientes foram maiores na proporção de 30\% de mistura Portanto, recomenda-se a mistura de materiais ao lodo na proporção de $30 \%$ para a produção de vermicomposto.

Termos para indexação: Vermicomposto, lodo de esgoto, materiais de volume, metais pesados, Eisenia foetid.

\section{(Received in may 19, 2010 and approved in july 6, 2011)}

\section{INTRODUCTION}

There are a large amount of sewage sludge produced in wastewater treatment plants that caused potential risks for human health and environmental problems (BAZRAFSHAN et al., 2005) . Sewage sludge can use as organic fertilizer and soil amendment, but its odors, heavy metal content, toxic organic compounds, and pathogens show the necessity of treatment and stabilization before application to farm lands (TIQUIA et al., 2002). Stricter regulations governing the discharge of sewage into waters and the escalating costs of alternate disposal procedures and chemical fertilizers have increased interest in using land to dispose of municipal sewage sludges and effluents (KELLEY et al., 1984). Some of beneficial effects of land application of sewage sludge are supplying nutrients (N, P, secondary nutrients, and micronutrients), improving of soil physical conditions, and elevating of soil organic matter level. Heavy metals and organic pollutants concentration limits the use of sewage sludge as organic fertilizer (QUATMANE et al., 2000). Biological composting of sewage sludge stabilizes its organic content and decreases the pathogens population (BURGE; ENKIRI, 1978). Although, total concentration of heavy metals increase during composting, the available forms of them decline in this process; probably due to production of insoluble complexes with humic substances (PARÉ et al., 1999).

1University of Mohaghegh Ardabili - Department of Soil Science - Ardabil - Iran

${ }^{2}$ Islamic Azad University - Young Researchers Club - Ardabil - Iran - jamaati1361@yahoo.com 
According to Stover et al.,1967 findings, less than 17 percent of the total amount of $\mathrm{Cu}, \mathrm{Zn}, \mathrm{Pb}$, and $\mathrm{Cd}$ in sludges and approximately 22 percent of $\mathrm{Ni}$ are in the sorbed and exchangeable fractions, that is, the forms readily available to plants. The remainder of the metals is present in forms which require conversion to watersoluble, exchangeable, or sorbed forms before uptake by plants. Sommers (SOMMER, 1997) suggest that different chemical forms of a metal may predominate in different sewage sludges. Thus, the behavior of a metal after incorporation into the soil may not be similar for different sludges.

Use of earthworms in sewage sludge composting is a suitable technology for its management. The activity of earthworms helps to remain of aerobic condition and accelerates microbial decomposition. In this process increases the earthworm's biomass and leaves their castings rich from nutrients (BENITEZ et al., 1999). Mixing of bulking material to sewage sludge improves earthworm's activity and the quality of vermicompost (DOMINGUES et al., 1999). Gondek and Filipek-Mazur (GONDEK; FILIPEK-MAZUR, 2001) used from conifers saw dust, shredded cardboard, and wheat straw as bulking agents with the mixing proportion of $15 \%$ for vermicompost production from sewage sludge. Arumuga et al. ( ARUMUGA et al., 2004), in India, used from the mixture of sewage sludge, rice straw and manure for vermicompost production. Vigueros and Camperos ( VIGUEROS; RAMIREZ-CAMPEROS, 2002) used from water hyacinth as bulking material for vermicomposting of sewage sludge. Eastman et al. (EASTMAN et al., 2001) showed that fecal coliforms bacteria and helminthes ova in were significantly lower in vermicompost compare to compost produced from biosolids and vermicomposting is an alternative method for class a compost production.

The aims of this study were: 1) to determine chemical composition of produced vermicomposts from mixing of various bulking material with sewage sludge 2) to investigate their quality and suitability as organic fertilizer

\section{MATERIAL AND METHODS}

This study was carried out in glasshouse of University of Mohaghegh Ardabili under natural light condition. The experimental design was factorial with complete random blocks and three replications. The main factor was type of bulking materials and their mixing proportion with sewage sludge was as subordinate factor. Final dried sewage sludge were collected from
Tabriz city sewage treatment plant and mixed with bulking materials (shredded wheat straw, wood chips, and shredded tree leaves) in the proportions of 0,15 , 30 , and $45 \%(\mathrm{~V} / \mathrm{V})$ and filled in 4 litter black coloured plastic pots. To determine proper time of earthworm application, 10 mature worms were added in weekly intervals and their survival was investigated. After one month and sure from the residence of earthworms, 100 mature worms from Eisenia foetida species were added to the experimental pots. The moisture of materials was controlled close to $70 \%$ of saturation based on pot's weight and water sprayed to avoid drying of material's surface. After 5 months of incubation of pots, the colour of materials turned to dark brown black and the activity of worms declined that these conditions indicated the maturity of vermicomposts. At this time, vermicomposts were harvested and analyzed to determine their chemical properties.

The $\mathrm{pH}$ and the electrical conductivity of the sludge were measured in a suspension of 1:5 materials and distilled water. For all samples (sludge, bulking materials, and vermicomposts) one gram of grounded samples dried-ash in a muffle furnace at $550^{\circ} \mathrm{C}$, extracted with $2 \mathrm{M} \mathrm{HCl}$, and analyzed to yield the total concentrations of important nutrients and other elements (JONES et al., 1991). Organic carbon was measured by Walckly Black method; Total nitrogen with Kejeldahl method using an automated apparatus, Grehardt model 2020 (BOLTS; HOWELL, 1978); total P with ascorbic acid spectroscopic method (BOLTS; HOWELL, 1978); total $\mathrm{Na}$ and $\mathrm{K}$ by flame photometer; total $\mathrm{Ca}$ and $\mathrm{Mg}$ by complexometery (SPARKS, 1996). Total concentration of heavy metals include $\mathrm{Fe}, \mathrm{Mn}, \mathrm{Zn}, \mathrm{Cu}, \mathrm{Pb}, \mathrm{Cd}, \mathrm{Co}$, and $\mathrm{Ni}$ were determined by atomic absorption instrument, Perkin Elmer model 640 (JONES, 2001).

Data were analyzed by one-way ANOVA in a general linear model, using SAS statistical software (SAS, 1990). LSD Multiple Range Test was applied to compare the means of elemental composition of the samples.

\section{RESULTS AND DISCUSSION}

Chemical characteristics of sewage sludge and bulking material that used in the experiment were shown in Table 1. Sewage sludge had neutral $\mathrm{pH}$ and low EC that shows suitability for plants growth. The $\mathrm{C}$ : $\mathrm{N}$ ratio of sludge was lower than suitable values for vermicomposting process. This result showed the necessity of application of bulking materials with high $\mathrm{C}$ content. Ndegwa and Thomson (NDEGWA; THOMSON, 
Table 1 - Analyses of variance nutrient contents and chemical properties of Type of bulking material (TM), Mixing proportion (MP) and TM $\times$ MP used in the experiment.

\begin{tabular}{|c|c|c|c|c|}
\hline \multirow[b]{2}{*}{ Properties } & \multicolumn{4}{|c|}{ Mean square } \\
\hline & Replication & $\begin{array}{c}\text { Type of bulking } \\
\text { material (TM) }\end{array}$ & $\begin{array}{c}\text { Mixing } \\
\text { proportion }(\mathrm{MP})\end{array}$ & $\mathrm{TM} \times \mathrm{MP}$ \\
\hline $\mathrm{PH}$ & $0.298^{* *}$ & $31.298^{* *}$ & $32.42^{* *}$ & $<0.0001^{* *}$ \\
\hline $\mathrm{EC}$ & $0.009^{* *}$ & $1.3^{* *}$ & $1.17^{* *}$ & $0.000^{* *}$ \\
\hline $\mathrm{OC}$ & $33.02^{* *}$ & $3.302^{* *}$ & $10.43^{* *}$ & $45.83^{* *}$ \\
\hline $\mathrm{N}$ & $0.075^{* *}$ & $0.224^{* *}$ & $0.367^{* *}$ & $<0.001^{* *}$ \\
\hline $\mathrm{P}$ & $0.187^{\mathrm{ns}}$ & $0.31^{\mathrm{ns}}$ & $0.22^{\mathrm{ns}}$ & $0.00^{\mathrm{ns}}$ \\
\hline $\mathrm{K}$ & $0.0001^{\mathrm{ns}}$ & $0.0004^{\mathrm{ns}}$ & $0.00036^{\mathrm{ns}}$ & $0.00056^{\mathrm{ns}}$ \\
\hline $\mathrm{Ca}$ & $1.25^{* *}$ & $1.707^{* *}$ & $3.84^{* *}$ & $0.57^{* *}$ \\
\hline $\mathrm{Mg}$ & $0.0559^{* *}$ & $0.136^{* *}$ & $0.185^{* *}$ & $0.0139^{* *}$ \\
\hline $\mathrm{Fe}$ & $1474223^{* *}$ & $206584.6^{* *}$ & $517042^{* *}$ & $271378^{* *}$ \\
\hline $\mathrm{Cu}$ & $1197.8^{* *}$ & $814.7^{* *}$ & $1457.4^{* *}$ & $338.7^{* *}$ \\
\hline Mn & $6493.3^{* *}$ & $21679.8^{* * *}$ & $20268.1^{* *}$ & $0.000^{* *}$ \\
\hline $\mathrm{Zn}$ & $81.03^{* *}$ & $8720.37^{* *}$ & $274.81^{* *}$ & $8965.19^{\text {** }}$ \\
\hline $\mathrm{Pb}$ & $2.06^{* *}$ & $72928.5^{* *}$ & $36744.3^{* *}$ & $7923.8^{* *}$ \\
\hline $\mathrm{Ni}$ & $3.89^{* *}$ & $48.19^{* *}$ & $26.46^{* *}$ & $55.57^{* *}$ \\
\hline Co & $2.43^{* *}$ & $2.37^{* *}$ & $26.27^{* * *}$ & $19.91^{* *}$ \\
\hline $\mathrm{Cd}$ & $4.14^{* *}$ & $9.51^{* *}$ & $7.25^{* *}$ & $2.61^{* *}$ \\
\hline
\end{tabular}

$* *, *$ and $\mathrm{ns}$, significant in $1 \%, 5 \%$ and not significant, respectively.

2000) reported that the $C: N$ ratio of $25: 1$ for starting materials in vermicomposting process of sewage sludge resulted in maximum stability, highest fertilizer value, and minimum potential environmental pollution. Total concentration of $\mathrm{P}$ was high, probably due to carbon evolvement and reduction of sludge volume in decomposition stages in treatment steps. Atieh et al. 2000 suggested that rapid break down of $\mathrm{C}$ compounds and $\mathrm{CO}_{2}$ evolution from the manure could lead to a decrease of biomass and consequent increase of vermicompost nutrients content.

Chemical composition of bulking materials used for vermicompost production was also represented in Table 1. $\mathrm{C}$ : $\mathrm{N}$ ratio of wood chips and wheat straw were lower that reported values for these wastes (80:1, and 500:1, respectively) (GUPTA et al., 1977). Partial decomposition of materials might cause to decrease of their $\mathrm{C}$ : $\mathrm{N}$ ratio. Wood chips had higher $\mathrm{C}$, and $\mathrm{C} / \mathrm{N}$ content and lower content of other nutrients compare to other bulking materials. A comparable data was reported by Hashemimajd, 2010 .

It seems that since sewage sludge had much higher $\mathrm{P}$ content than bulking material and in decomposition process much of bulking material's carbon was lost, therefore, the $\mathrm{P}$ content of vermicomposts did not significantly different. On the other hand, losses of potassium during vermicomposting process caused to hinder the effect of bulking materials in potassium concentration of sewage sludge vermicompos. Wortmann et al. 2007 confirmed the loss of potassium during composting of different organic wastes.

The effects of type and mixing proportion of bulking materials on chemical composition of produced vermicompost were shown in fingers 1-3. Addition of bulking materials decreased the $\mathrm{pH}$ of vermicompost compare to control, proportional to mixing percentage with sewage sludge. The amount of $\mathrm{pH}$ reduction was greater when woodchips was used as bulking material. Reduction of $\mathrm{pH}$ during vermicomposting process might due to production of organic acids and insertion of $\mathrm{Ca}$ to earthworm's body. There was contradictory data in literature about the change of $\mathrm{pH}$ in vermicomposting process. Hashemimajd et al., 2006 reported the increment of $\mathrm{pH}$ in vermicomposting process for mixture of sewage sludge and wood chips, while Atiyeh et al. 2000 showed the $\mathrm{pH}$ of manure was decreased in vermicomposting. The higher reduction of $\mathrm{pH}$ in wood chips might due to higher $\mathrm{CO}_{2}$ Production in this 
treatment that caused to produced more organic acids including $\mathrm{H}_{2} \mathrm{CO}_{3}$. Sundberg et al., 2004 reported organic acids are produced during initial phases of composting. Electrical conductivity (EC) of vermicomposts were higher than initial sewage and might due to mineralization of organic compounds during vermicomposting process. Hashemimajd et al., 2006 confirm EC enhancement during vermicomposting of saw dust. Organic carbon (OC) content of vermicomposts was higher than original sewage sludge But there was no distinct trend among the effect of type and mixing proportion of bulking material on vermicomposts OC (Figure 1). Application of bulking materials also reduced $\mathrm{N}$ content of vermicompost compare to initial sewage sludge and its effect was proportional to the bulking material mixing percentage. These results might due to higher $\mathrm{C}$ and lower $\mathrm{N}$ content of bulking material compare to sewage sludge. Nitrogen concentration of vermicomposts in 30 mixing proportion was higher than that of $45 \%$ treatment.
It probably showed the higher stability of $30 \%$ treatment (Figure 2). Arumuga et al. 2004 pointed out that the C content of materials was deceased while the $\mathrm{N}$ content was increased and there were no significantly differences, in this respect, between kinds and mixing proportion of bulking material. Nakashi et al. 2001 found that saw dust is the most effective material for avoiding $\mathrm{N}$ loss as $\mathrm{NH}_{3}$ from compost piles and its effect is proportional with mixing proportion. Wortmann et al. 2007 declared that bulking material decrease $\mathrm{C} ; \mathrm{N}$ ratio of wastes and reduce the $\mathrm{N}$ losses during the process.

Addition of bulking material elevated the $\mathrm{Ca}$, $\mathrm{Mg}, \mathrm{Fe}, \mathrm{Cu}, \mathrm{Mn}$, and $\mathrm{Zn}$ contents of produced vermicomposts than that of control. Silva et al. 2002 showed that $\mathrm{Ca}$ and $\mathrm{Mg}$ concentration were increased in vermicomposts. In most cases the concentration of these elements was higher again in $30 \%$ mixing proportion. The concentration of $\mathrm{Mg}$ was greater in pots containing wood chips (Figure 1), probably
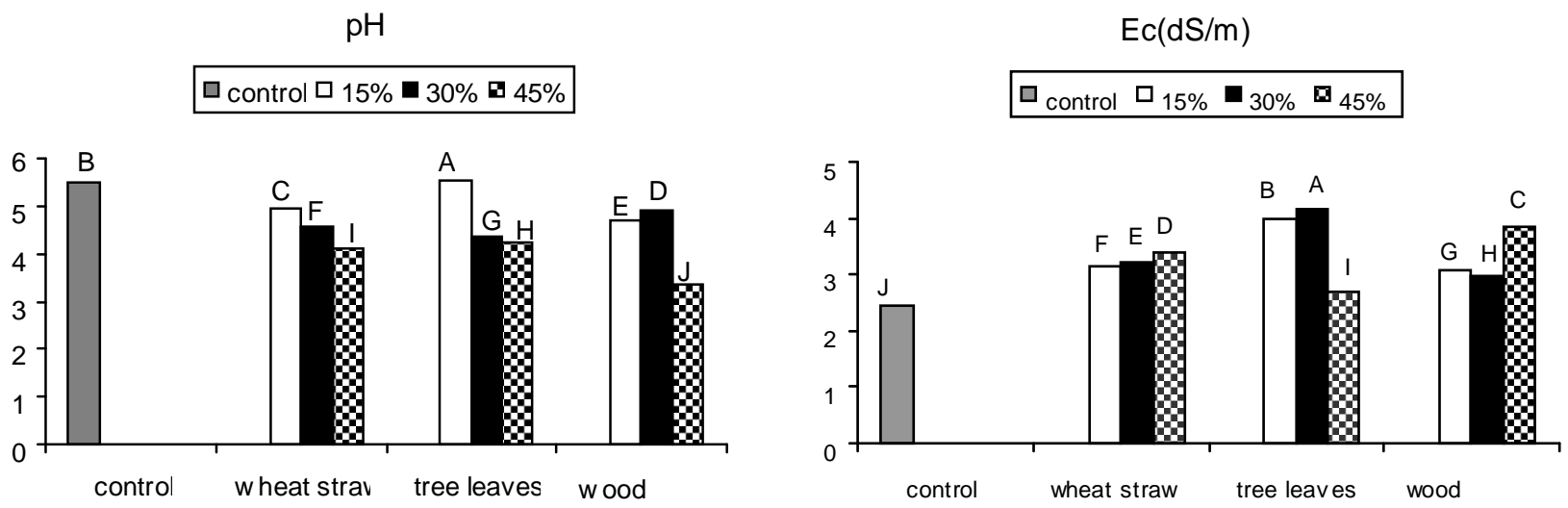

Organic Carbon (\%)

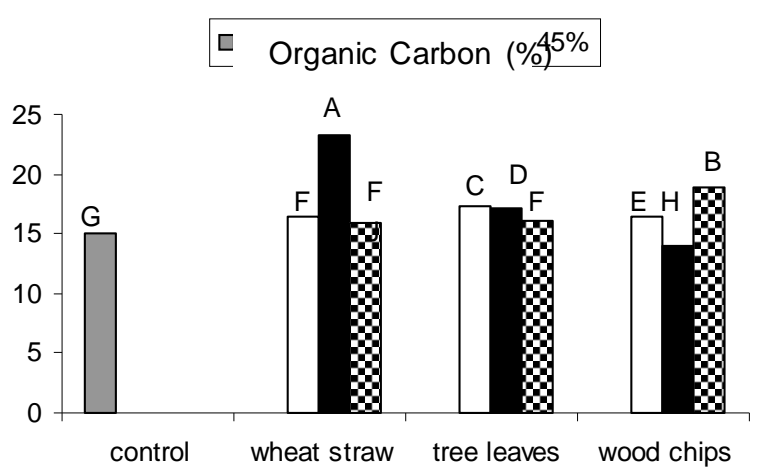

Figure $1-\mathrm{pH}, \mathrm{EC}$, and percentage of organic carbon of vermicomposts in different treatments, columns showed with similar capital letters have not significantly difference at $5 \%$ level (Duncan multiple range test).

Ciênc. agrotec., Lavras, v. 35, n. 6, p. 1077-1084, nov./dez., 2011 


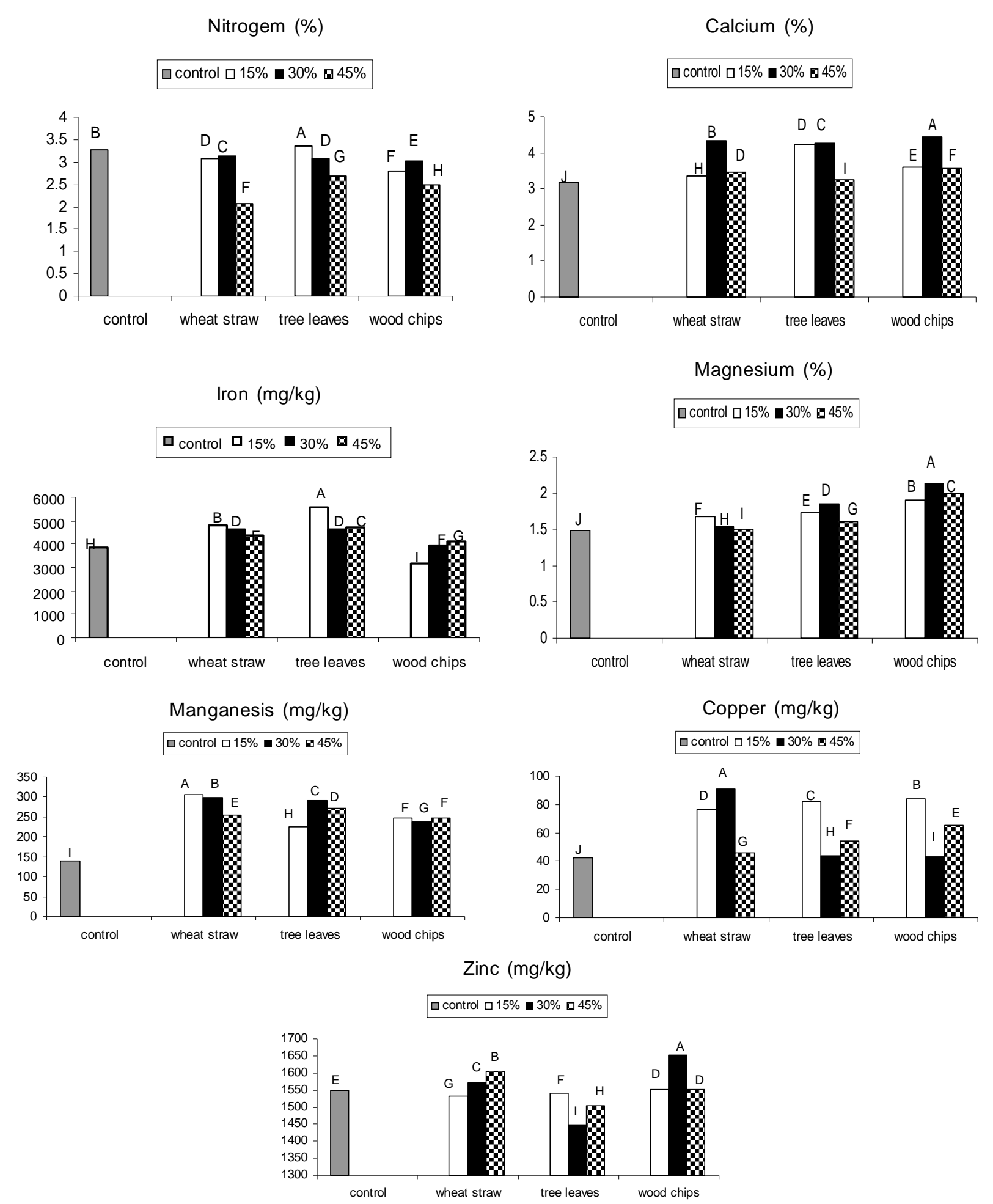

Figure 2 - Percentage of nitrogen, calcium, magnesium and concentration of iron, manganesis, copper and zinc in produced vermicomposts, columns showed with similar capital letters have not significantly difference at $5 \%$ level (Duncan multiple range test). 
reflected the higher concentration of this element in initial wood chips (Table 1). The iron content was higher of vermicompost in tree leaves and sludge mixture but lower in wood chips containing treatments. There was no distinct trend in the concentration of $\mathrm{Cu}$ in different treatments. Sommers, 1997 confirmed that the $\mathrm{Cu}$ content of sewage sludge is very variable. Wheat straw and wood chips added treatments had highest and lowest Mn conten, respectively. The concentration of $\mathrm{Zn}$ was lower in the tree leaves incorporated treatments. Increasing of nutrient concentration of final vermicompost in bulking material added might due to evolvement of $\mathrm{CO}_{2}$ and increase the concentration of other nutrients (ATIYEH et al., 2000).

Addition of bulking materials were decreased the concentrations of $\mathrm{Pb}, \mathrm{Co}$, and $\mathrm{Cd}$ but increased $\mathrm{Ni}$ contents of them. (Figure 3). Some researchers declared that changes of heavy metal concentration in vermicomposting process depend on the elemental composition and chemical properties of sludge. Manios; Stenifored, 2006 reported that $\mathrm{Zn}$ concentration of vermicompost produced from 1:1 mixing of sewage sludge and olive leaves (V/V) was more than 1:2 mixing proportion and $\mathrm{Pb}$ concentration was higher in $1: 2$ mixture but $\mathrm{Ni}$ concentration was similar in both treatment. Concentration of heavy metals except $\mathrm{Zn}$ was lower that standard limit recommended by US EPA (RENNER, 2000). Concentration of $\mathrm{Zn}$ was slightly higher than acceptable level (1500 mg/kg). Numerous reports confirmed that the concentration of heavy metals in sewage sludge vermicompost as in acceptable limits (EASTMAN et al., 2001; PARVARESH et al., 2004; SILVA et al., 2002; VIGUEROS; RANIREZ-CAMPEROS, 2002).
Cobalt (mg/kg)

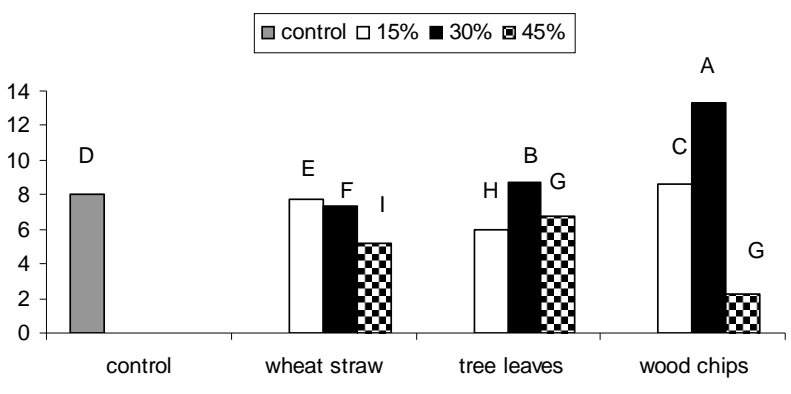

Cadmium $(\mathbf{m g} / \mathrm{kg})$

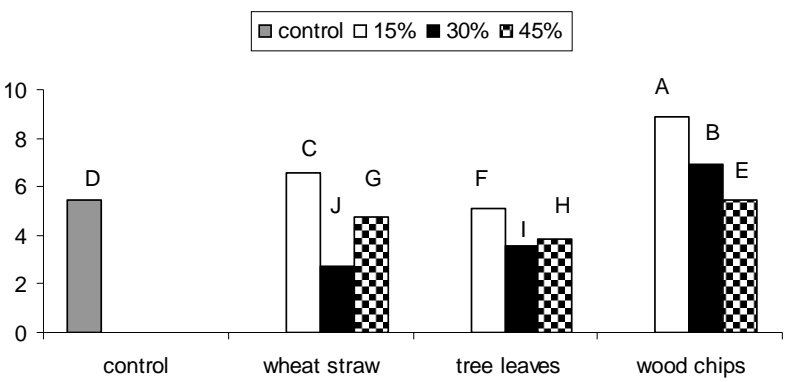

$\operatorname{Lead}(\mathbf{m g} / \mathbf{k g})$

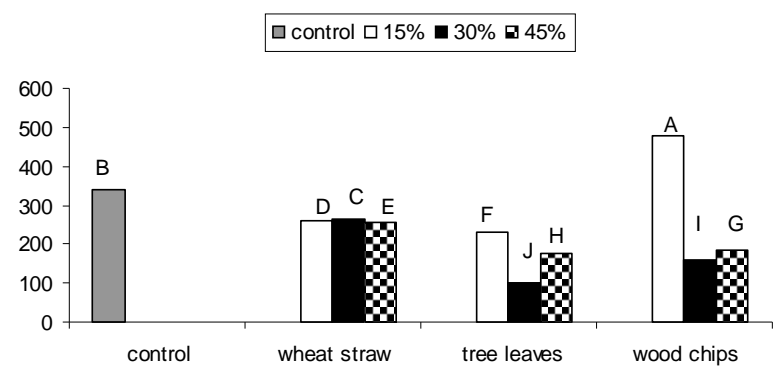

Nickel (mg/kg)

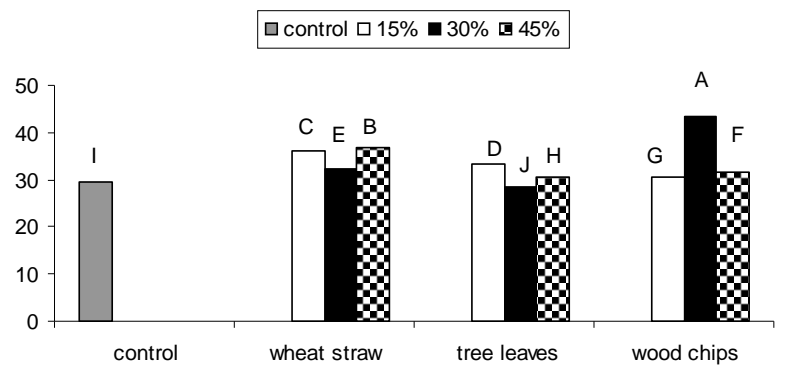

Figure 3 - Concentration of cobalt, lead, cadmium and nickl in vermicompost, columns showed with similar capital letters have not significantly difference at $5 \%$ level (Duncan multiple range test). 


\section{CONCLUSION}

Sewage sludge vermicomposts have low $\mathrm{pH}$, low salinity, and high nutrients content. Mixing of bulking materials with sewage sludge reduced $\mathrm{pH}, \mathrm{N}, \mathrm{Pb}, \mathrm{Co}$, and $\mathrm{Cd}$ concentration while increased $\mathrm{Ca}, \mathrm{Mg}, \mathrm{Fe}, \mathrm{Cu}, \mathrm{Mn}, \mathrm{Zn}$, and $\mathrm{Ni}$ content of vermicompost. The heavy metals concentration in vermicompost is in EPA recommended ranges. The concentrations of nutrient were higher in $30 \%$ of mixing proportion. Further researches about the effect of vermicomposts produced from different type of bulking materials and sewage sludge on soil properties and plants growth is recommended.

\section{REFERENCES}

ARUMUGA, G. K. et al. Municipal solid waste management through anaecic earthworm, Lampito Mauritti and their role in microbial modification. 2004. EcoService International, Available at: http:// www.eco-web.com/editorial/ 040831.html

ATIYEH, R. M. et al. Change in biochemical properties of cow manure during processing by earthworms (Eisenia anderi, Bouche') and effects on seedling growth. Pedobiologia v. 44, n. 6, p. 709-724. 2000.

BAZRAFSHAN, E. et al. Evaluation of Microbiological and chemical parameters during wastewater sludge and sawdust co-composting. Journal of Applied Sciences and Environmental Management, v.10, n.2, p. 115-119. 2005.

BENITEZ, E. et al. Enzyme activities as indicators of the stabilization of sewage sludges composting with Eisenia foetida. Bioresource Technology, v, 6, n. 3, p. 297-303. 1999.

BOLTS, D.F; J.A. HOWELL, Colorimetric

determination of nonmetals. USA. John Wley and Sons, 1978. p: 201-242.

BURGE, W. D.; N. K. ENKIRI. Virus Adsorption by Five Soils. Journal of Environmental Quality, v. 7, n. 1, p. 7376. 1978:

DOMINGUEZ, J.; C. A. EDWARDS, M.

WEBSTER. Vermicomposting of sewage sludge solids: effects of bulking materials on the growth and reproduction of the earthworm Eisenia andreii (Bouché). Pedobiologia, v. 43, n.4, p. 372-379. 1999.
EASTMAN, B. R. et al. The effectiveness of vermiculture in human pathogen reduction for USEPA biosolids stabilization. Compost Science \& Utilization, v. 9, n.1, p. 38-49, 2001.

GONDEK, K.; B. FILIPEK-MAZUR. Agricultural Usability of Sewage Sludge and Vermicompost of Tannery Origin. Electronic Journal of Polish Agricultural Universities. Environmental Development, v. 4, n. 2. 2001.Available at: http://www.ejpau.media.pl/ series/volume4/issue2/environment/art-01.html

GUPTA, S. C.; R. H. DOWDY; W. E. LARSON.. Hydraulic and thermal properties of a sandy soil as influenced by incorporation of sewage sludge. Soil Science Society of America Journal, v. 41, n. 3, p 601-605. 1977.

HASHEMIMAJD, K. Production of compost and vermicompost from organic wastes. Aeejh publisher. Tehran-Iran. 2010.

HASHEMIMAJD, K. et al. Use of vermicomposts produced from various solid wastes as potting media. European Journal of Horticultural Science, v. 71, n. 1, p. 21-29. 2006.

\section{JONES, J. B. Laboratory Guide for Conducting Soil Tests and Plant Analysis. CRC Press. Boca Raton, FL, 2001, pp. 27-160.}

JONES, J. B.; B. WOLF; H. A. MILLS. Plant Analysis Handbook: a practical sampling, preparation, analysis and interpretation guide. Macro- Micro Pub. Inc., Athens, GA, 1991. pp 23-37.

KELLEY, W. D. et al. Agricultural use of sewage sludge: a literature review. Department of Agronomy Virginia Polytechnic Institute and State University. Bulletin 143, p. 46.1984.

MANIOS, T.; E. I. STENIFORED. Heavy metals fractionation during the thermophilic phase of sewage sludge composting in aerated static piles. Journal of Environmental Science and Health Part A, v. 41, n. 7, p. 1235-1244. 2006.

NAKASHI, K.; A. OHTAKI; H. TAKANO. Effect of bulking agent on the reduction of $\mathrm{NH}_{3}$ emmision during thermophilic composting of night-soil sludge. Waste Management \& Research, v. 19, n. 4, p. 301-307. 2001. 
NDEGWA, P. M.; S. A. THOMSON. Effect of C to N ratio on vermicompostiong of biosolids. Bioresource

Technology, v. 75, n. 1, p. 7-12. 2000.

PARÉ, T.; H. DINEL; M. SCHNITZER. 1999.

Extractibility of trace metals during co-composting of biosolids and municipal solid wastes, Biology and Fertility of Soils 29: 31-37.20.

PARVARESH, A., H. MOVAHEDIAN, L. HAMIDIAN. Investigation of chemical quality and fertilizer value of vermicompost produced from sewage sludge of Isfahan city. Water and Sewage, v. 15, n.2, p. 29-32. 2004a. (In: Persian).

PARVARESH, A.; SHAHMANSOURI, M. R. ALIDADI, $H$. Determination of carbon/nitrogen ratio and heavy metals in bulking agents used for sewage composting. Iranian Journal of Public Health, v. 33. n. 2, p. 20-23. 2004.

QUATMANE, A. et al Compost maturity assessment using calorimetery, spectroscopy and chemical analysis. Compost Science \& Utilization, v. 8, n. 2, p. 124-134. 2000.

RENNER, R. 2000. Sewage Sludge, Pros \& Cons. Environmental Science \& Technology, v. 34, p. 19. Available at: http://www.mindfully.org/Pesticide/SewageSludge-Pros-Cons.htm

SAS Institute. 1990. SAS Proceeding Guide, Version 6. $3^{\text {rd }}$ ed., SAS Institute, Cray, NC.

SILVA, C. D.; COSTA, L. M.; MATOS, A. T. Vermicomposting of urban sewage sludge and sugarcane bagasse. Revista Brasileira de Engenharia Agrícola e Ambiental, v. 6, n. 3 p. 487-491. 2002.

SPARKS, D. L. Methods of Soil Analysis, Part 3, Chemical Methods. SSSA Book Series Number 5, Soil Science Society of America, Madison, WI. 1996.

SOMMERS, L. E. Chemical composition of sewage sludges and analysis of their potential use as fertilizers. Journal of Environmental Quality, v. 6, p. 225-32. 1977.

STOVER, R. C.; SOMMERS, L. E.; SILIVAN, D. J.

Evaluation of metals in wastewater sludge. Journal Water Pollution Control Federation, v. 48, n. 9: 2165-2175. 1976.

SUNDBERG, C.; SMARS,S.; JONSSON, H. Low pH as an inhibiting factor in transition from mesophilic to termophilic phase in composting. Bioresource Technology., v. 95.n. 2, p. 145-150. 2004.

TIQUIA, S. M.; WAN, J. H. C.; TAM, N. F. Y. Microbial population dynamics and enzyme activities during composting. Compost science \& utilization v. 10, n. 2, p. 150-161.2002.

VIGUEROS, C.; RAMIREZ-CAMPEROS, E. 2002. Vermicompostiong of sewage sludge: a new technology for Mexico. Water science and technology, v. 46, n. 10, p. 153-158.

WORTMANN, C. S.; SHAPIRO, C. A.; TARKALSON, D. D. Composting manure and other organic residue. University of Nebraska Extension Website. 2007.Available in: http://www. Progressivedairy.com/ anm/features/2007/0507/0507_composting.html 